\title{
Original Paper \\ Small Parmeliaceae (liquenized Ascomycota) of Ilhabela State Park and nearby areas, São Paulo state, Brazil
}

\author{
Michel Navarro Benatti ${ }^{1,3,4}$ \& Neli Kika Honda ${ }^{2}$
}

\begin{abstract}
A survey of lichens at Ilhabela State Park and nearby areas in São Sebastião Island revealed the occurrence of 12 taxa belonging to six genera of small foliose Parmeliaceae, which are characterized by usually small thalli (hardly $>10 \mathrm{~cm}$ in diameter) with narrow lobes or laciniae less than $1 \mathrm{~cm}$ wide. Comments are provided for the species registered.

Key words: Atlantic rainforest, lichens, mycobiota, restinga wood, São Sebastião Island.

\section{Resumo}

O levantamento de liquens no Parque Estadual de Ilhabela e seus arredores na Ilha de São Sebastião revelou a ocorrência de 10 táxons pertencentes a seis gêneros de pequenas Parmeliaceae foliosas, caracterizadas pelos talos geralmente pequenos (dificilmente $>10$ centímetros de diâmetro), com lobos ou lacíneas estreitas de largura inferior a $1 \mathrm{~cm}$. São apresentados comentários para as espécies registradas.

Palavras-chave: Mata Atlântica, liquens, micobiota, restinga, Ilha de São Sebastião.
\end{abstract}

\section{Introduction}

With the 16th longest coastline in the world, the Brazilian Atlantic coastline extends over nearly 7.5 thousand kilometers, comprising many geographical features, including beaches, bays, reefs, and islands (CIA 2017). The Atlantic Rainforest represents the major vegetation type found in many coastal areas, including the islands. The diversity of lichens still remains poorly investigated in most coastal formations, such as restinga woods, mangroves, and rocky shores.

Parmeliaceae is the most representative family in Brazilian biomes with regard to the diversity of genera and species (Marcelli 1998). During the past two decades, it has been the focus of Brazilian researchers, who showed the occurrence of hundreds of species, including new records and new species. Several recent surveys have significantly contributed to the diversity and distribution of small Parmeliaceae genera like Bulbothrix Hale, Canoparmelia Elix \& Hale, Crespoa Lendemer \& Hodkinson, Hypotrachyna (Vain.) Hale, Parmelinopsis Elix \& Hale, Parmelinella Elix \& Hale, and Relicina (Hale \& Kurok.) Hale (e.g., Benatti 2011, 2012a-h, 2013a-c, 2014a-c; Benatti \& Elix 2012; Benatti \& Lendemer 2014; Benatti \& Marcelli 2007; Benatti et al. 2008; Canêz et al. 2009; Gerlach \& Eliasaro 2012, 2014; Jungbluth et al. 2008; Marcelli \& Canêz 2008; Marcelli et al. 2007, 2011; Spielmann \& Marcelli 2008a,b). The small Parmeliaceae comprises species easily recognizable by their small thalli (usually $<10 \mathrm{~cm}$ diameter) with narrow lobes or laciniae (often $<1 \mathrm{~cm}$ wide).

Recently, a survey of foliose lichens in Cananéia, Cardoso, Comprida, and Ilhabela

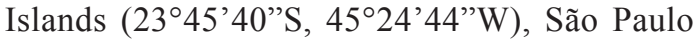
state, reported 16 species of Leptogium (Kitaura

\footnotetext{
${ }^{1}$ Instituto de Botânica, Núcleo de Pesquisa em Micologia, C.P. 3005, 01061-970, São Paulo, SP, Brasil.

${ }^{2}$ Universidade Federal de Mato Grosso do Sul - UFMS, Inst. Química, Av. Sen. Filinto Müller 1555, 79074-460, Campo Grande, MS, Brasil.

3 ORCID: <https://orcid.org/0000-0002-2625-4194>

${ }^{4}$ Author for correspondence: michel_benatti@yahoo.com.br
} 
et al. 2017), however, the lichen diversity at this region remains largely unexplored. In the present study, we aimed at identifying the species of small Parmeliaceae that occur at Ilhabela Island, state of São Paulo, Brazil.

\section{Material and Methods}

Specimens of small foliose Parmeliaceae were collected at Ilhabela $\left(23^{\circ} 45^{\prime} 36^{\prime}\right.$ 'S, $45^{\circ} 24^{\prime} 36^{\prime}$ 'W) State Park, São Paulo state, Brazil, during several field expeditions from 2012 to 2013. Vegetational types include mostly Atlantic Rainforest, with Restinga Wood along the Eastern Coast. Accordingly to the climate classification of Köppen-Geiger, the island is classified as Tropical Aw. The altitude ranges from sea level up to almost $1400 \mathrm{~m}$. The methodology used for the collection and study of lichenized fungi is described in Fink (1905), Hale (1979, 1987), Malcolm \& Galloway (1997) and Benatti \& Marcelli (2007). Collected specimens were observed under an Eikonal EK3ST stereomicroscope and Motic TYPE 102M microscope and the macroscopic and microscopic characteristics of somatic and reproductive structures of the thalli were analyzed. Identification was performed by comparison of published descriptions of specimens from different locations. Chemical tests consisted in spot tests, UV light exposure $(360 \mathrm{~nm})$, microcrystal tests and Thin Layer Chromatography (TLC) in the following eluents: (I) toluene: ethyl acetate: acetic acid $6: 4: 1 \mathrm{v} / \mathrm{v} / \mathrm{v}$ and (II) toluene: acetic acid 85:15 v/v, following the methodology described in Asahina \& Shibata (1954), Walker \& James (1980), White \& James (1985), Huneck \& Yoshimura (1996) and Orange et al. (2001). All collected specimens were deposited at SP herbarium.

\section{Results and Discussion}

Thirty specimens of small Parmeliaceae were studied. We identified ten species belonging to Bulbothrix Hale (one species), Canoparmelia Elix \& Hale (two), Crespoa Lendemer \& Hodkinson (one), Parmelinella Elix \& Hale (two), Parmelinopsis Elix \& Hale (three) and Remototrachyna Divakar \& Crespo (one), which are commented below.

Due to the presence of a constantly dense ombrophilous forest, it was difficult to find thalli that were mature or not damaged by chlorosis or necrosis. Even with a high search effort, almost all thalli in the study area were found in small open areas such as clearings, posts, lookouts, roadsides, and near water courses or waterfalls. We were not able to examine and identify some of the specimens collected due to the fragmented and depleted condition of the badly damaged thalli.

\section{Species registered}

1. Bulbothrix ventricosa (Hale \& Kurok.) Hale. Phytologia 28(5): 481. 1974. MB 341620.

Parmelia isidiza var. domingensis Vain., Annales Academiae Scientarum Fennicae 6A(7): 17. 1915.

Species description: Hale (1976b); Benatti (2012d).

Specimens examined: Ilhabela, Parque Estadual de Ilhabela, Ilha de São Sebastião, Cachoeira da Toca old farm, 234' $\mathrm{S}, 45^{\circ} 21^{\prime} \mathrm{W}, 6 . \mathrm{XII} .2012$, leg., M.N. Benatti et al. 3412, 3413, 3418; Cocaia track, entrance to Costabela, 15.V.2013, leg., M.N. Benatti et al. 3533.

This is one of the most common species of Bulbothrix in several Brazilian vegetation types (Benatti 2012d). It is mainly recognized by its larger lobed aspect (with rounded and broad lobes, often between 1 and $5 \mathrm{~mm}$ wide) compared to other Bulbothrix species, its distinct bulbate cilia with simple apices, the varied (often mottled) coloration of the lower cortex and the presence of medullary norstictic acid (the latter two characteristics also common to the non-isidiate B. viatica Spielmann $\&$ Marcelli). Our specimens were poorly developed with 2 to $3 \mathrm{~cm}$ in diameter (with the exception of a single larger, $6 \mathrm{~cm}$-wide thallus), and the presence of laciniae of often small width (only a few $>3$ $\mathrm{mm}$ wide). The laminal ciliar bulbs were scarce to common, and most specimens showed darkly mottled lower cortices, with a predominance of dark brown and black shades. All specimens have plenty of isidia, although no apotheciate material was found. The presence of atranorin and norstictic acids were confirmed by TLC.

2. Canoparmelia caroliniana (Nyl.) Elix \& Hale. Mycotaxon 27: 278. 1986. MB 128704.

Parmelia caroliniana Nylander, Flora 68:

614. 1885.

Species description: Benatti (2014c).

Specimens examined: Ilhabela, Ilhabela State Park, Ilha de São Sebastião, Cocaia track, entrance to Costabela, $23^{\circ} 47^{\prime}$ 'S, $45^{\circ} 21^{\prime}$ W, 15.V.2013, leg., M.N. Benatti, L.B. Moro \& C. Mayumi 3532, 3538, 3555, 3357.

The isidiate $C$. caroliniana together with the sorediate $C$. texana (Tuck.) Elix \& Hale are among the most common Canoparmelia species 
found in Brazil, even in urbanized or other types of anthropized areas. Interestingly, the specimen M.N. Benatti et al. 3357 presented a more accentuate medullary reaction to spot tests (almost as reddish as expected for $C$. sanguinea Marcelli, Benatti \& Elix) but TLC confirmed traces of perlatolic acid derivatives. Although confirmed by TLC, the perlatolic acid was not clearly evidenced due to the low concentration found. This might due to the contact with other species that are growing on the same substrate and have similar compounds which could have been leached by rainfall. The atranorin and chloroatranorin acids might have occurred at low concentrations or even been absent in our material, as they were not detected on the plates.

3. Canoparmelia cryptochlorophaea (Hale) Elix \& Hale. Mycotaxon 27: 278. 1986. MB 128708.

Parmelia cryptochlorophaea Hale, The Bryologist 62: 18. 1959.

Species description: Hale (1976a, as Pseudoparmelia cryptochlorophaea).

Specimens examined: Ilhabela, Ilhabela State Park, track close to the meteorological station near the lookout, $23^{\circ} 47^{\prime}$ S, 45⒉ 'W, 4.IX.2012, leg., M.N. Benatti et al. 3370; municipal plant nursery Cachoeira da Água

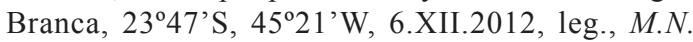
Benatti et al. 3425; SABESP area, southern part of the island, Bairro Bixiga, $23^{\circ} 47^{\prime} \mathrm{S}, 45^{\circ} 21^{\prime} \mathrm{W}, 06 . \mathrm{XII} .2012$, leg., M.N. Benatti et al. 3456 (p.min.p.); Bairro da Feiticeira, $23^{\circ} 47^{\prime} \mathrm{S}, 4^{\circ} 21^{\prime} \mathrm{W}, 6 . \mathrm{XII} .2012$, leg., M.N. Benatti et al. 3461.

This species was cited for the first time for the state of São Paulo by Jungbluth (2006), who collected specimens at several spots of Cerrado vegetation in the interior of the state. This is the first record for coastal areas. The presence of capitate and raised marginal soralia and the medullary reaction to spot tests $(\mathrm{K}+$ faintly rose and $\mathrm{KC}+$ purple rose) are characteristic of this species. The KC reaction for the specimen M.N. Benatti 3370 gave a more purple-reddish tone. The presence of cryptochlorophaeic acid was confirmed, although atranorin might have occurred at low concentrations as it was not detected in the TLC plate. We examined several specimens of different species from the study area that presented low concentrations of atranorin, which has a solar light filter function, and interestingly, all these specimens were collected from relatively shaded places and reacted to K spot tests, showing the presence, albeit weak, of the substance. Like the specimens found by Jungbluth (2006), our specimens did not have ascomata or pycnidia.

4. Crespoa cf. scrobicularis (Kremp.) Benatti \& Lendemer, Brittonia 66: 288. 2014. MB 802265.

Parmelia scrobicularis Kremp., Videnskabelige Meddelelser Naturhistorik Forening Kjöbenhavn 25: 10. 1873.

Species description: Benatti \& Lendemer (2014).

Specimens examined: Ilhabela, Ilhabela State Park, southern part of the island, 27.VI.2012, $23^{\circ} 47^{\prime}$ 'S, $45^{\circ} 21^{\prime}$ 'W, leg., M.N. Benatti, L. Moro \& M. Boro 3335.

We collected a single specimen that was growing together with a specimen of Heterodermia $\mathrm{sp}$. This species is characterized by the scrobiculate thallus. Atranorin, stictic and constictic acids were confirmed by TLC and menegaziaic acid was not present. An unidentified substance with $\mathrm{Rf}$ close to 43 was found solely in eluent I, but it could not be determined. As the specimen of $C$. scorbicularis was growing together with a species of Heterodermia, the substance might have leached from the later to our specimen. The thallus did not produce apothecia, pycnidia, soredia or isidia, as in the case of several other specimens found in the study area and as the propagule-producing species C. crozalsiana (B. de Lesd. ex Harm.) Lendemer \& Hodk. and C. carneopruinata (Zahlbr.) Lendemer \& Hodk. Therefore, it could only be identified as Crespoa cf. scrobicularis, which has been previously reported for other areas in the state of São Paulo (Jungbluth 2006; Benatti 2014b).

5. Parmelinella cinerascens (Lynge) Benatti \& Marcelli. Opuscula Philolichenum 11: 27. 2012. MB 563647.

Parmelia cinerascens Lynge, Arkiv før Botanik 13 (13): 104. 1914.

Species description: Benatti (2012h).

Specimens examined: Ilhabela, Ilhabela State Park, Cocaia track, entrance to Costabela, 15.V.2013, 23ํㄱ's, $45^{\circ} 21^{\prime} \mathrm{W}$, leg., M.N. Benatti, I.H. Schoenlein-Crusius \& C. Mayumi 3548.

We found only a single specimen at the study area. This species is easy recognizable due to the presence of small lobes, axillary or marginally sparse cilia that are very short and simple, a black lower cortex and medullary salazinic acid. It is similar to Parmelinella salacinifera, from which it differs by the paler and brown lower cortex, and the scarce to absent simple cilia. This material was one of the few well-developed thalli of small 
Parmeliaceae found (approximately $8 \mathrm{~cm}$ wide), very isidiate and with a single, relatively mature apothecium. The hymenia, however, did not present asci with mature ascospores.

6. Parmelinella salacinifera (Hale) Marcelli \& Benatti. Mycosphere 5: 780. 2014. MB 810474.

Parmelia salacinifera Hale. Contributions from the U.S. National. Herbarium 36: 157. 1964. Species description: Benatti (2014a).

Specimens examined: Ilhabela, Ilhabela State Park, Cocaia track, entrance to Costabela, 15.V.2013, 234' 'S, $45^{\circ} 21^{\prime} \mathrm{W}$, leg., M.N. Benatti, I.H. Schoenlein-Crusius \& C. Mayumi 3540 .

This isidiate species is similar to $P$. cinerascens, but is promptly identified by its pale brown lower cortex and the very scarce to absent marginal or axillary simple short cilia. It also presented medullary salazinic acid, which is common for Parmelinella spp. We were not able to elucidate if all specimens identified under this name belong to a single species, although they are overall nearly identical in morphology, anatomy and chemistry to all specimens described in Benatti (2014a). The only difference found was regarding the frequency of the tiny marginal cilia, with specimens completely eciliate, with a few cilia, to some with cilia in a few parts of their marginal area (Benatti 2014a). As in the case of most species registered in the present study, we only found one specimen.

7. Parmelinopsis damaziana (Zahlb.) Elix \& Hale. Mycotaxon 29: 242. 1987. MB 130583.

Parmelia damaziana Zahlbr. Bulletin de 1'Herbier Boissier 5: 541. 1905.

Species description: Hale (1976c)

Specimens examined: Ilhabela, Ilhabela State Park, track close to the meteorological station near the lookout,

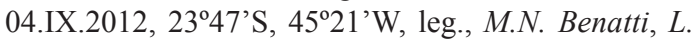
Moro, M. Boro \& C. Mayumi 3365.

The only specimen collected was fertile with plenty of mature apothecia. This species commonly present hyaline, simple, ellipsoid to subglobose ascospores that measure $(8-) 10-15(-16) \times 8-12$ $\mu \mathrm{m}$, and does not produce neither soredia nor isidia. Its morphological and chemical varieties are discussed in detail by Jungbluth (2006), but overall the single specimen examined herein was similar to those described by this author for Cerrado areas of São Paulo state. The chromatographic analysis showed the presence of atranorin and also of an unidentified substance (with a well-marked spot) with Rf 43 in the eluent 2. According to literature and simultaneous experiments, this substance might be 2,4-di-O-metilgiroforic acid, also found by Jungbluth (2006) for P. damaziana growing on Cerrado vegetation. Besides the perceptible but evanescent medullary reaction $\mathrm{KC}+$ reddish-rose, other components, even possibly giroforic acid, were at too low concentrations in the extract to be detected.

8. Parmelinopsis cf. minarum (Vain.) Elix \& Hale. Mycotaxon 29: 243. 1987. MB 130590.

Parmelia minarum Vain., Acta Societatis pro Fauna et Flora Fennica 7: 48. 1890.

Species description: Benatti (2012e).

Specimens examined: Ilhabela, Parque Estadual de Ilhabela, track close to the meteorological station near

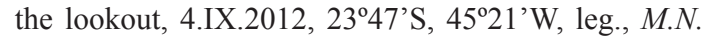
Benatti, L. Moro, M. Boro \& C. Mayumi 3358, 3368 , 3371; Municipal plant nursery Cachoeira da Água

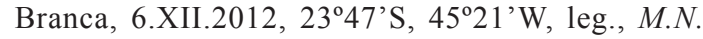
Benatti, L. Moro \& C. Mayumi 3447; eastern part of the island, around Praia de Castelhanos and restinga

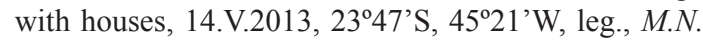
Benatti, H. Schoenlein-Crusius, L. Moro \& C. Mayumi 3500, 3509; Cocaia track, road to Costabela, 15.V.2013, $23^{\circ} 47^{\prime}$ S, $45^{\circ} 21^{\prime} \mathrm{W}$, leg., M.N. Benatti, I.H. SchoenleinCrusius \& C. Mayumi 3556.

This species, together with P. spumosa, are one of the most common small Parmeliaceae found at the study area. It is easily recognizable in the field due its narrow and short laciniate thallus and the isidiate upper cortex. Most specimens collected, however, consisted of very small thalli of less than $4 \mathrm{~cm}$ wide, except for a single one of approximately $7 \mathrm{~cm}$ wide. The chromatographic analysis showed a few differences between specimens. Atranorin was overall present but some specimens presented three medullary compounds while others had two substances of the gyrophoric tridepsides group. Analysis by microcrystalization did not show the presence of gyrophoric acid. We were not able to compare the chromatographic behaviour due to the absence of data in the literature, but it appears to be related to the $P$. horrescens complex. In this study, we found only one specimen (M.N. Benatti et al. 3368) that had mature apothecia but unfortunately, the hymenium was damaged. The specimens M.N. Benatti et al. 3500 and 3368 both showed a similar chromatographical profile. The collection of more specimens and the use of other analytical techniques such as Liquid Chromatography-Mass Spectrometry (LC-MS) are needed for a conclusive characterization of these substances. 
9. Parmelinopsis spumosa (Asahina) Elix \& Hale. Mycotaxon 29: 243. 1987. MB 130596.

Parmelia spumosa Asahina, Journal of Japanese Botany 26: 259. 1951.

Species description: Benatti (2012e).

Specimens examined: Ilhabela, Ilhabela State Park, track close to the meteorological station near the lookout, 4.IX.2012, 234ㄱ'S, $45^{\circ} 21^{\prime}$ W, leg., M.N. Benatti, L. Moro, M. Boro \& C. Mayumi 3354, 3355, 3359, 3360, 3372.

This species is easily recognizable by its eciliate thallus with coarse sorediate bursting pustules, differing from similar species such as P. subfatiscens, which is also eciliate but has non sorediate pustules. The chromatographical analysis showed some differences between specimens. All specimens examined contained atranorin but most had at least three other medullary compounds (some specimens contained two compounds). The low production of some substances and the leeching of other substances from other lichens present on the same substrate could justify these discrepancies. Using microcrystalization, only one thalli clearly showed presence of gyrophoric acid. Other compounds could not be determined, as documented by Jungbluth (2006) for specimens from Cerrado. The specimens M.N. Benatti et al. 3360 and 3289 were partially different chromatographically. The specimen M.N. Benatti et al. 3360 showed presence of three tridepsides together with atranorin, whereas the specimen M.N. Benatti et al. 3289 showed only two tridepsides with atranorin. Besides this difference, we were not able to make further identifications of substances using microcrystalization.

The substances present in the specimens of both $P$. minarum and P. spumosa were tridepsides derived from orcinol (e.g., Hüneck \& Yoshimura 1996). However, the chromatographical profiles and microcrystalization tests did not show the presence of gyrophoric acid (although they reacted $\mathrm{C}+$ and $\mathrm{KC}+$ rose- reddish, as expected for this substance in spot tests), even with the eluents tested (I and II) and microcrystal preparations. Again, most specimens were quite small with a few centimetres wide and therefore, they could not be used for further tests without destroying the whole specimens.

10. Remototrachyna ef. costaricensis (Nyl.) Divakar \& Crespo. Taxon 97: 586. 2010. MB 546535.

Parmelia costaricensis Nyl. Journal of Botany British and Foreign 13: 225.1877.
Species description: Spielmann \& Marcelli (2008b).

Specimens examined: Ilhabela, Ilhabela State Park, southern part of the island, 27.VI.2012, 23 ${ }^{\circ} 53^{\prime}$ 'S, $45^{\circ} 25^{\prime}$ 'W, leg., M.N. Benatti, L. Moro \& M. Boro 3336; Cachoeira da Toca old farm, 6.XII.2012, 23ํㄱ' 'S, $45^{\circ} 21^{\prime}$ W, leg., M.N. Benatti, L. Moro \& C. Mayumi 3408; Cocaia rack, road to Costabela, 15.V.2013, 23ํㄱ'S, $45^{\circ} 21^{\prime}$ 'W, leg., M.N. Benatti, I.H. Schoenlein-Crusius \& C. Mayumi 3531 .

This species was the only Parmeliaceae with dichotomously branched rhizines (previously in Hypotrachyna before recent studies confirmed that a group of species comprised another genus) found at the study area. It presented relatively large laciniae (up to $5 \mathrm{~mm}$ wide, i.e. broader and more rotund than in other species of Parmelinopsis) and abundant isidia. Atranorin and chloroatranorin were not detected by chromatography, possibly due to their low concentrations in the specimens (as the $\mathrm{K}+$ yellow reaction occurred in the spot tests). The chromatography showed also three spots (Rfs around 35, 40 and 45 in eluent I) that we were not able to identify. The chemistry variability is yet not fully comprehended (e.g., Nash et al. 2002; Louwhoff \& Elix 2002; Jungbluth 2006) but this is currently the only known isidiate species with dichotomously branched rhizines that show no medullary reaction to any spot tests $(\mathrm{K}, \mathrm{C}, \mathrm{KC}$, and $\mathrm{P}$ ).

The specimens M.N. Benatti et al. 3531 and 3336 were slightly different chromatographically, but both contained atranorin. The spots revealed with the $p$-anisaldehyde: sulfuric acid indicated that the substances might belong to the class of terpenes, since fatty acids are not revealed with this substance. Microcrystalization also did not show the presence of fatty acids, including protoliquesterinic and caperatic acids. Constipatic acid is very difficult to detect with this technique. Flakus et al. (2011) reported the presence of atranorin, constipatic acid complex $( \pm$, only very rarely absent) and an unidentified pigment ( \pm , only in one specimen). Our results are in agreement with the substances reported by Flakus et al. (2011) in Bolivian specimens. It is possible that some of the specimens collected in South America and identified as $R$. costaricensis could represent chemotypes, since it is still premature to confirm that they belong to different species.

Aside from our work on the genus Leptogium (Kitaura et al. 2017) there are no other inventories of lichens in the study area. Therefore, this study adds new and further information to the diversity of 
the local mycobiota. In addition, it represents one of the few surveys (e.g., Benatti 2012b,d) performed hitherto in areas of the Atlantic Rainforest.

\section{Acknowledgements}

We are indebted to the reviewers for their valuable contribution, which contributed significantly to the improvement of this final version.

\section{References}

Asahina Y \& Shibata S (1954) Chemistry of Lichen Substances. Japan Society for the Promotion of Science, Tokyo. 239p.

Benatti MN (2011) A simple clearing technique to aid in the recognition of cilia and rhizinae structure in the Parmeliaceae. Opuscula Philolichenum 9: 21-25.

Benatti MN (2012a) Pequenas espécies de Parmeliaceae ciliadas no Parque Estadual da Cantareira, estado de São Paulo, Brasil: gêneros Bulbothrix, Parmelinella e Parmelinopsis (Parmeliaceae, Ascomycota). Hoehnea 39: 207-218.

Benatti MN (2012b) New species of Bulbothrix Hale containing gyrophoric acid from Brazil. Mycology 3: $127-131$.

Benatti MN (2012c) Three resurrected species of the genus Bulbothrix Hale (Parmeliaceae, Lichenized Fungi). Mycosphere 3: 46-55.

Benatti MN (2012d) A review of the genus Bulbothrix Hale: the species with medullary norstictic or protocetraric acids. MycoKeys 2: 1-28.

Benatti MN (2012e) Pequenas espécies de Parmeliaceae ciliadas no Parque Estadual da Cantareira, estado de São Paulo, Brasil: gêneros Bulbothrix, Parmelinella e Parmelinopsis (Parmeliaceae, Ascomycota). Hoehnea 39: 207-218.

Benatti MN (2012f) A worldwide key for the genus Parmelinopsis Elix and Hale (Parmeliaceae; Lichenized Ascomycetes). Opuscula Philolichenum 11: 304-312.

Benatti MN (2012g) A review of the genus Bulbothrix Hale: the species with medullary salazinic acid lacking vegetative propagules. MycoKeys 5: 1-30.

Benatti MN (2012h) Canoparmelia cinerascens belongs in the genus Parmelinella (Parmeliaceae, lichenized Ascomycota). Opuscula Philolichenum 11: 26-30.

Benatti MN (2013a) A review of the genus Bulbothrix Hale: species with gyrophoric, lecanoric or lobaric acids lacking vegetative propagules. Opuscula Philolichenum 12: 151-173.

Benatti MN (2013b) A review of the genus Bulbothrix Hale: the species with medullary fatty acids or without medullary substances. Mycosphere 4: 303-331.

Benatti MN (2013c) A review of the genus Bulbothrix Hale: the isidiate, sorediate and pustulate species with medullary salazinic acid. Mycosphere 4: 1-30.
Benatti MN (2014a) An update on the genus Parmelinella Elix \& Hale (Parmeliaceae, lichenized ascomycetes). Mycosphere 5: 770-789.

Benatti MN (2014b) Pequenas espécies de Parmeliaceae (Ascomycota) eciliadas no Parque Estadual da Cantareira, estado de São Paulo, Brasil: gêneros Canoparmelia e Crespoa. Rodriguésia 65: 587-597.

Benatti MN \& Elix JA (2012) The true identity of Bulbothrix goebelii (Zenker) Hale and the reestablishment of some of its synonyms as accepted species. The Lichenologist 44: 813-826.

Benatti MN \& Lendemer JC (2014) Canoparmelia scrobicularis belongs to the genus Crespoa (Parmeliaceae, lichenized Ascomycota). Brittonia 66: 287-291.

Benatti MN \& Marcelli MP (2007) Gêneros de fungos liquenizados dos manguezais do sul-sudeste do Brasil, com enfoque no manguezal do Rio Itanhaém, estado de São Paulo. Acta Botanica Brasilica 21: 863-878.

Benatti MN, Marcelli MP \& Elix JA(2008) Canoparmelia sanguinea, a new Parmeliaceae from Brazil. Mycotaxon 106: 435-439.

Canêz LS, Marcelli MP \& Elix JA (2009) New Brazilian species of Canoparmelia with medullary olivetoric, anziaic, and sekikaic complexes. Mycotaxon 110: 465-472.

CIA - Central Intelligence Agency (2017) "Coastline." cia.gov. Central Intelligence Agency. Available at $<$ https://www.cia.gov/library/publications/theworld-factbook/elds/2060.html>. Access on 02 June 2020.

Fink B (1905) How to collect and study lichens. The Bryologist 8: 22-27.

Flakus A, Oset M, Jabłońska A, Saavedra PM \& Kukwa M (2011) Contribution to the knowledge of the Lichen Biota of Bolivia. 3. Polish Botanical Journal 56: 159-183.

Gerlach A \& Eliasaro S (2012) Liquens parmelioides eciliados (Parmeliaceae, Ascomycota) em costões rochosos dos estados do Paraná e Santa Catarina, Brasil. Acta Botanica Brasilica 26: 570-584.

Gerlach A \& Eliasaro S (2014) Espécies de Parmeliaceae (Ascomycota) ciliadas e sem máculas reticulares em costões rochosos dos estados do Paraná e de Santa Catarina. Brasil 41:321-336.

Hale ME (1976a) A monograph of the lichen genus Pseudoparmelia Lynge (Parmeliaceae). Smithsonian Contributions to Botany 31: 1-62.

Hale ME (1976b) A Monograph of the Lichen Genus Bulbothrix Hale (Parmeliaceae). Smithsonian Contributions to Botany 32: 1-29.

Hale ME (1976c) A monograph of the lichen genus Parmelina Hale (Parmeliaceae). Smithsonian Contributions to Botany 33: 1-60.

Hale ME (1979) How to know the Lichens. The Pictured-Key Nature Series. WMC Brown Company Publishers, Dubuque. 246p. 
Hale ME (1987) How to know the lichens. $2^{\text {nd }}$ ed. WCB/ McGraw-Hill, Boston. 246p.

Huneck S \& Yoshimura I (1996) Identification of Lichen Substances. Springer, Berlin. 492p.

Jungbluth P (2006) A família Parmeliaceae (fungos liquenizados) em fragmentos de cerrados do estado de São Paulo. Dissertação de Mestrado. Instituto de Botânica, São Paulo. 300p.

Jungbluth P, Marcelli MP \& Elix JA (2008) Five new species of Bulbothrix (Parmeliaceae) from cerrado vegetation in São Paulo state, Brazil. Mycotaxon 104: 51-63.

Kitaura MJ, Augusto BO \& Benatti MN (2017) New records of Leptogium species in Brazil with identification key to insular species from São Paulo state. Current Research in Environmental \& Applied Mycology 7: 129-143.

Louwhoff SHJJ \& Elix JA (2002) Hypotrachyna and allied lichen genera in Papua New Guinea. Bibliotheca Lichenologica 81: 1-149.

Malcolm WM \& Galloway DJ (1997) New Zeland Lichens: checklist, key and glossary. Museum of New Zeland Te Papa Tongarewa, Wellington. 192p.

Marcelli MP (1998) Diversidade dos fungos liquenizados no estado de São Paulo: um diagnóstico. In: Joly CA \& Bicudo CEM (eds.) Biodiversidade do estado de São Paulo, Brasil: síntese do conhecimento ao final do século XX. Vol. 2. FAPESP, São Paulo. Pp. 25-35.

Marcelli MP \& Canêz LS (2008) Novelties on Southern Brazilian Parmeliaceae. Mycotaxon 105: 225-234.
Marcelli MP, Jungbluth P, Benatti MN, Spielmann AA, Canêz LS, Cunha IPR \& Martins MFN (2007) Some new species and combinations of Brazilian lichenized fungi. Bibliotheca Lichenologica 96: 209-227.

Marcelli MP, Canêz LS, Benatti MN, Spielmann AA, Jungbluth P \& Elix JA (2011) Taxonomical novelties in Parmeliaceae. Bibliotheca Lichenologica 106: 211-224.

Orange A, James PW \& White FJ (2001) Microchemical methods for the identification of lichens. The British Lichen Society, London. 101p.

Spielmann AA \& Marcelli MP (2008a) Parmeliaceae (Ascomycota liquenizados) nos barrancos e peraus da encosta da Serra Geral, Vale do Rio Pardo, Rio Grande do Sul, Brasil. I. Introdução e chave para os gêneros. Iheringia Série Botânica 63: 159-170.

Spielmann AA \& Marcelli MP (2008b) Parmeliaceae (Ascomycota liquenizados) nos barrancos e peraus da encosta da Serra Geral, Vale do Rio Pardo, Rio Grande do Sul, Brasil. II. Gêneros Canoparmelia, Hypotrachyna, Myelochroa, Parmelinopsis e Relicina. Iheringia Série Botânica 63: 193-212.

Walker JW \& James PW (1980) A revised guide to microchemical techniques for the identification of lichen products. British Lichen Society Bulletin 46: 13-29.

White FJ \& James PW (1985) A new guide to microchemical techniques for the identification of lichen substances. British Lichen Society Bulletin 57: $1-41$. 